\title{
Formation Aspects of an Accessible Environment in Modern Landscape Architecture in Azerbijan
}

\section{Aspekty formacyjne dostępnego środowiska we współczesnej architekturze krajobrazu w Azerbejdżanie}

\author{
Farid Karimov
}

\author{
Department of Landscape Architecture, \\ Faculty of Architecture, Azerbaijan University of Architecture and Construction \\ A.Sultanova, 11, AZE-1073, Baku, Azerbaijan \\ E-mail:farid.kerimov@mail.ru
}

\begin{abstract}
Despite the recent complex reconstruction in Azerbaijan, public spaces, parks and boulevards still do not fully respond to inclusivity. A long-term comprehensive action plan should be developed, and targeted actions should be undertaken to address these short comings. Thus, in order to achieve full accessibility, equipment and construction should be carried out not only in parks, but also in public spaces, taking into account the needs and interests of people with different categories of disability. It is also necessary to improve the regulatory framework, to promote public awareness, to develop a positive attitude towards physically challenged people, and to train new generations of professionals to take action to ensure a high level of working on this field in the future.
\end{abstract}

Key words: landscape architecture, inclusiveness, mobility impairments, barrier-free environment, universal design

\section{Streszczenie}

Pomimo przeprowadzanej skomplikowanej przebudowy Azerbejdżanu przestrzenie publiczne, parki i bulwary nadal nie w pełni spełniają kryteria inkluzywności. Należy więc opracować długoterminowy kompleksowy plan działania, aby zaradzić tym niedociągnięciom. Stąd, aby osiągnąć pełną dostępność, urządzenia i konstrukcje należy instalować nie tylko w parkach, ale także w przestrzeni publicznej, uwzględniając potrzeby i interesy osób z różnymi kategoriami niepełnosprawności. Konieczne jest również ulepszenie ram regulacyjnych, promowanie świadomości społecznej, kształtowanie pozytywnego nastawienia do osób niepełnosprawnych fizycznie oraz szkolenie nowych pokoleń specjalistów do podejmowania działań w celu zapewnienia wysokiego poziomu pracy w tej dziedzinie w przyszłości.

Słowa kluczowe: architektura krajobrazu, inkluzywność, niepełnosprawność ruchowa, środowisko bez barier, uniwersalny projekt

Architecture can be empowering, only if architects develop empathy

Raymond Lifchez, Architect, author of the book Design for Independent Living

\section{Introduction}

When referring to the people with disabilities, first our society incorrectly implies visually and hearing impaired including those who use wheelchairs. Actually, this group refer to children, the elderly, people of short stature, taller people, parents with babies in strollers, pregnant women, including people with neurological and mental impairments, people with autism and even tourists having troubles with landmark and language in a foreign location. Creating accessible environment for these people is one of priorities of the social environment of any government. Today, modern society is guided by the 
principles of compliance with the interests of people with disabilities and sets new goals for architects, builders and designers.

One of the important factors of the environment is its accessibility. A barrier-free environment protects people's health by preventing situation to cause injury and disabilities, and promotes the work and social integration of people with impairments. Recently, attention to this problem is growing in our country and abroad. This is especially due to the adoption by the UN in December 2006 of the Convention on the Rights of Persons with Disabilities (The Convention on the rights of persons with disabilities, 2006). However, the history of this issue spans several decades. Efforts to create an barrierfree environment abroad related with the emergence of a large number of people with various physical and mental impairments after World War II. In the early 1950s, the Council of Europe launched a commission to address the issues of creating a habitat that meets the needs of persons with disabilities. In the 1960s and 1970s, norms and standards regulating architectural activities and meeting the requirements of disabled people appeared in Europe. The first planning recommendations for creating a barrierfree environment in the USSR were developed in the late 1980s. Based on them, Guidelines for the Movement of Persons with Disabilities Using a Wheelchair in Public Building Projects, Planning and Development of Residential Areas were published.

Sustainable Development Goals in the field of inclusiveness in Azerbaijan, especially in Baku, can be explained as follows:

1. Integrated provision in all areas of inclusiveness;

2. Formulating norms and requirements based on international practice and national mental values to ensure inclusiveness;

3. Development of an appropriate legal normative base;

4. Development of a mechanism to monitor the implementation of laws adopted by the State;

5. Development of government programs for the training of new generation specialists in all areas to properly organize future inclusiveness;

6. Conducting awareness activities forming public perception about the attitude towards people with disabilities and their correct treatment;

7. Providing psychological support for people with disabilities to make them feel comfortable in society;

8. Organization of inclusiveness in all spheres of tourism of non-oil sector, which in recent years has been an relevant State strategy in Azerbaijan;
9. To ensure inclusive transport network among all regions of Azerbaijan by providing inclusiveness;

10. To ensure involvement of people with physical disabilities in working groups in the implementation of all these processes.

At present, there are some requirements approved by laws and regulations of Azerbaijan to create barrierfree environment for people with disabilities. However, despite the existence of these standards, they are not always met. The main problem of existing buildings in Azerbaijan is the lack of accessibility. People with disabilities in multi-storey buildings spontaneously arrange ramps for themselves from stairs and entrances, equip apartments on the first floors with a flat ramp. But all this must be done in accordance with accepted norms and requirements, based on the experience of other countries in the world. Nevertheless, our country should also master the production of specialized devices for the people with disabilities.

Each of us in different periods of life get different degree of disability. It can be temporary or permanent due to some disease, age, pregnancy and many other reasons. In short, disability ${ }^{1}$ is a complex situation, which numerous people deal with at a certain time frame for various reasons. But what is considered by people with mobility impairment:

- People with locomotor impairment

- Visually impaired people

- Hearing impaired people

- People with mental impairments

- People with psychiatric impairments

- People with invisible disabilities This also includes the following:

- The elderly

- Children

- Pregnant women and parents with small children

- $\quad$ Short stature and taller people

- Overweight people

- People with strollers or wheelchairs for baggage and cargo transportation

- People with temporary injuries (sprain, fracture, etc.)

- Foreign citizens

Also:

- Medical personnel and the emergency

- Emergency service

According to statistics for 2019, to date, 611,496 people with different degrees of disability have been registered in Azerbaijan If we add people belonging to the groups listed above to this number, we can say with complete confidence that the problem of inclusiveness of the urban environment belongs to more than half of the population.

\footnotetext{
${ }^{1}$ Law of the Republic of Azerbaijan On the Rights of
} Persons with Disabilities of May 31, 2018 No. 1153-VQ. 


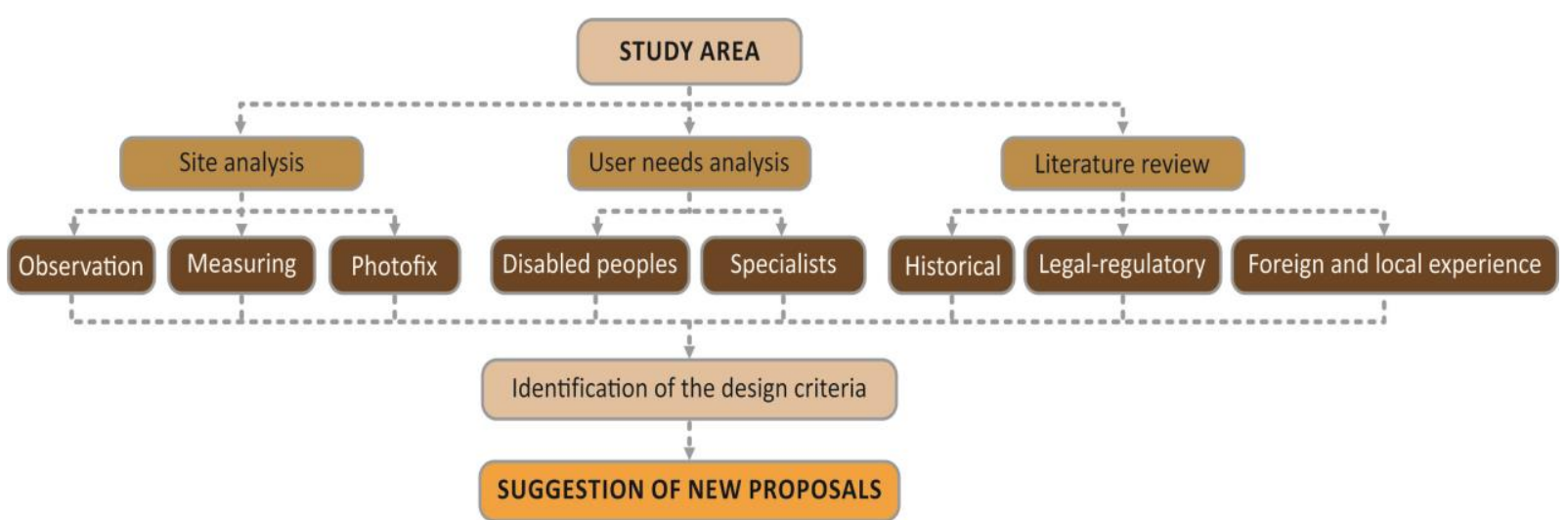

Scheme 1. The basic framework of the study

Not a small number at all.

Nowadays, large-scale reconstruction works are carried out in all regions of Azerbaijan, as well as in the capital city Baku, the city infrastructure is renewed, streets, gardens and parks improved, new transport hubs created, greenery planted, open areas meeting modern requirements delivered for use by the population. But, along with all this, we are not able to say that Baku and other cities are fully accessible today. To achieve this, it is not enough just to remove obstacles on the roads running into parks, install new ramps on the streets, avenues and crossroads. This requires the elimination of stress factors, which are a sensitive issue for people with limited opportunities and disabilities, and the improvement of comfort in green areas.

If we analyze the open areas in our cities from this point of view, we see that there are practically no conditions for mobility impairments: obstacles, ascents, descents, steps, stairs, lack of handrails, tactile pavings, information boards and so on. People with disabilities, particularly those who use wheelchairs, are not able only to move freely in the parks and gardens, and enjoy the greenery, they can't even get out of their homes and get close to these places. In the winter months, the situation worsens, and the lack of an accessible environment forces these people to live in their apartments in a limited way.

\section{Material and methods}

Empirical, theoretical and historical methods were used during the study. Thus, the empirical method is based on observations, measurements, descriptions, etc. that investigate the level of inclusivity in the selected area of the study area - the open spaces of Baku, where the defects are visually recorded or photo-fixed. The materials obtained were, in some cases, confirmed by measurements and described in writing. The theoretical approach is based on the comparative method, which facilitates the comparative study of international experience, existing norms and requirements, as well as the models proposed by the author to address the shortcomings. All these results are based on the historical method, the work that has been done so far in the international arena and in our country to address the problem of inclusivity, with the stages of formation of public opinion on people with disabilities, the knowledge of the history of the concept of groups of people with disabilities and universal design. The structure of the research is as presented on scheme 1 .

\section{Historical background}

The lack of an accessible environment in our cities is not a problem of recent years. And this situation is observed not only in Azerbaijan, but also in the entire post-Soviet space. In fact, there are historical reasons why our cities today are not inclusive and still do not take disability factor into account in architectural design. Thus, according to the ideology of the Soviet system, in which we were part for more than 70 years, there could not be disabled person in the flourishing Soviet Union. 2.5 million persons with disabilities were registered after World War II alone (Volkova, 2016). Disloyal attitude prevailed towards such people in the USSR. Soviet citizens could not be impaired. People who received no social assistance other than a small pension, lost their body part during the war or were disabled for some other reason, in many cases had to beg. And the Soviet state, as part of its fight against such negative elements of society, offered, and in some cases even forced them to move to specially created homes for disabled veterans. Over time, as a result of such measures, beggars from the streets, albeit partially, began to decline. Some of the disabled settled in boarding schools, while some did not leave their homes. All these measures put the concept of an inclusive environment on the back burner in the Soviet area or, to be more precise, consciously were forgetting issues related to people with disabilities.

In the 1950s and 1960s, the situation for disabled children growing up and being brought up in boarding schools was partially good. Here they grew up with Soviet ideology, received education and medical care, believed that everyone was equal in the Soviet Union. After reaching adulthood, they left the boarding school and realized how difficult it was to 
have a disabled life outside the native walls. Wheelchairs were not sufficiently in the Soviet Union. Besides of this, no accessibility were taken into account for the movement by these means, and there could be no talk of inclusiveness.

Already from the mid of 1960 s to the early 1980 s, independent civic activity - dissident movements began to dominate in the public scene. Thus, in May 1978, dissident disabled persons, Yuri Kiselyov, Valeriy Fefelov and Faizulla Husainov created an Initiative Group for the Protection of the Rights of Persons with Disabilities in the USSR. It was the first informal alliance of human rights defenders established in the USSR in May 1969, a group that submitted general statements, but without a clear structure and charter. The group, which had done a great deal of work to protect persons with disabilities, was considered an anti-Soviet. The Committee for State Security started to chase Fefelov, Kiselev and $\mathrm{Hu}-$ sainov. Excerpted from the book There are no disabled people in the USSR! by Fefelov: The organizers of sports competitions held in Stoke Mandeville, England invited Soviet athletes to take part in these competitions. In response, Soviet leaders: 'There are no invalids in the USSR'! (Fefelov, 1986)

Attitudes towards disabled people only in the last decades of the USSR began to change for the better. In the 1970s and 1980s, the Soviet government adopted many laws aimed at increasing the level of Social Security: the disabled were given various benefits, the pension and health system improved. The first guidelines for the planning a barrier-free environment were developed in the late 80s. On their basis, Guidelines were published for ensuring the movement of wheelchairs in public building projects, planning and development of residential areas.

\section{International practice}

In the middle of the last century, not only in the USSR, but also in many countries of the world, there were significant events related to the protection of people with disabilities. Thus, in Berkeley, USA riots began in the streets, organized by Ed Roberts, a great advocate of inclusiveness (Isachenko, 2019). Ed Roberts, who suffered from polio and partially paralysis at childhood was a rebel by nature and a man of strong character. In a short time, he formed the Rolling Quads, bringing together like-minded students from around the world. Members of the group began to fight for the civil rights of persons with disabilities through radical and provocative methods. Activists with heavy hammers broke the sidewalks, preventing them from moving on the streets with wheelchairs. In the result, the Berkeley authorities was compelled to respond to all these demonstrations and provide ramps for the residents. The 60s and 70s, the USA was remembered for numerous civil reforms and mass riots. Movements to protect the rights of people with disabilities extended from Berkeley to all the states. Those who used a wheelchair held pickets in front of government organizations, prevented transport, in short, tried to attract the attention of the authorities. As a result, President Bush signed the Americans with Disabilities Act (ADA) in 1990, act on the rights of Americans with a disability (Adata.org, 2021).

Today the Ed Roberts Campus, located in Berkeley, California, USA, with an area of 7 thousand square meters, has become worldwide model of accessibility and versatility (Isachenko, 2019). Headquarters of the Center for Independent Living is in this building, designed by Leddy Maytum Stacy Architects (LMS Architects) and named after Ed Roberts, the defender of people with disabilities. It provides training, education, medical and legal services for people with disabilities and sensory issues. The building designed with 7 Principles of Universal Design is still fully compliant with the requirements of ADA. It uses acoustic landmarks, high contrast walls and textured floors to independently determine the direction of the visually impaired. The elevators are equipped with buttons at leg level. Doors can be operated remotely. There are no stairs, and it is possible to climb to the second floor with a red ramp, the object of focus in the central atrium. Only natural materials were used in construction and interior decoration. The indoor air is regularly cleaned up and moistened with innovative filters. It is designed for the comfort of people with allergies, asthma and special chemical sensitivities. During the construction of the campus, the Ashby Bart Station was also upgraded as part of the inclusiveness. Today, as a result of comprehensive measures, hundreds of persons with disabilities can visit this island of inclusivity.

It should also be noted that the work in this direction in various parts of the world is called differently: in the U.S. the term universal design (first used by the pioneer of this stream Robert Mace in 1985), in the UK it sounds like inclusive design, in the Nordic countries as design for all.

What does inclusive design in Robert Mace's theory mean? (Isachenko, 2019)

Inclusive (comprehensive) design means the design of objects, furniture, programs and services developed for the most convenient use by all people without the need for adaptation or special design. According to Robert Mace, inclusive design consists of 7 basic principles:

1. Equitable Use: The design should be developed for use by individuals with diverse physical abilities. Appealing design for all users.

2. Flexibility in Use: The design must meet a wide range of individual preferences and skills. It should help the user to get the product correctly and accurately. Rightand left-hand characteristics should be taken into account while using. 
3. Simple and Intuitive Use: The use of a product at this time should be understood by any user regardless of their experience, knowledge, language skills and level of concentration.

4. Perceptible Information: Regardless of the environmental conditions and the user's perception, the design must provide the user with the necessary information.

5. Tolerance for Error: Preventing unconscious actions in the performance of important tasks, minimizing threats and negative factors.

6. Low Physical Effort: The user should utilize the design as efficiently and comfortably as possible with minimum effort.

7. Size and Space for Approach and Use: Regardless of size, shape or mobility, any user should be provided with a comfortable approach to the product, access (transition), appropriate size and space for its manipulation and use.

Considering all this, the built-up spaces should not only meet the standards, but also be attractive, and have accessible landscape and architectural structures. In 2016 in the USA, the First National Study of Neighborhood Parks showed that only $4 \%$ of park visitors are the elderly (Isachenko, 2019). This indicates that it is necessary not to limit ourselves to standards of accessibility, when designing parks it is required to stimulate the desire of groups of people with special requirements to come to places, using landscape and architectural solutions that awaken a sense of psychological comfort. Designing a garden, a park, a street landscape is a very emotion-based activity. And the purpose of this work is to create feelings. Nobody likes the same, similar, sterile places nowadays. When it comes to parks, we are supposed to talk about the implementation of solutions that affect all our senses, awaken imagination and create cognitive contact with its location. Universal design today can be referred to an architectural ideology that brings together anyone who wants to make urban spaces as accessible, efficient, sustainable, aesthetic and economic as possible. Thus, the abovementioned principles of Universal Design were also used in the reconstruction of the International Trade Centre in New York and the construction of the 9/11 Memorial. The author of the project was architect Michael Arad and landscape architecture designer Peter Walker (Isachenko, 2019). The differences in the level of construction that prevailed at the memorial, which began in 2006, were replaced not by stairs but by inclination. These inclinations are solved so smoothly that most pedestrians do not even feel them. The names of the victims of the tragedy were written at such a height that they can be comfortably read by children, adults and those who use wheelchairs. Here people with disabilities can comfortably and without obstacles visit museums, cafes and auditoriums.

Another successful example of universal design is the yard of the Queen Elizabeth National Spinal Injuries Unit based in Glasgow (Isachenko, 2019). This project, developed by designer Cleve West, consists of six different green areas. Each area serves to develop the activation of different sensory organs and development of the sensory perception. The author of the idea of creating such a garden, contributing to the rehabilitation of patients, was a surgeon Horatio Chapple, a 17-year-old schoolboy. The young man worked here as an independent assistant, conducted a survey among patients and explored their opinions and wishes. Although the surgeon Horatio Chapple died tragically, his dream was fulfilled and the garden got incredible positive feedback in 2012. Obviously, a great role in the creation of such a therapeutic garden played a long experience of garden and park art of the English empire. But regardless of this, there must also be desire, good intentions and empathy.

\section{Research by design approach}

Nowadays, numerous projects can be observed designed to create an accessible environment as a result of large-scale reconstruction works of the streets in Baku. The ends of the sidewalks are equipped with ramps (Figure 1), and the streets and parks are provided with information and navigation boards (Figure 2), many crossings have lifts for people using wheelchairs and having problems with the locomotor system, parking lots have special seats for the disabled, public transport is provided by inclusive means of transport, revolving doors are installed almost in all public facilities, commercial and entertainment sites. Notwithstanding, our environment still cannot be considered accessible.

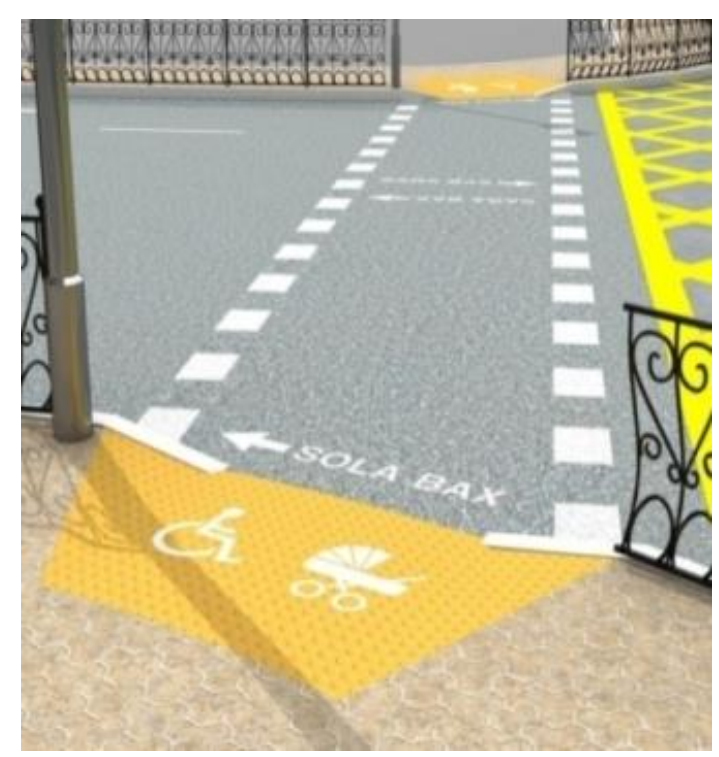

Figure 1. The new ramps in the streets of Baku 


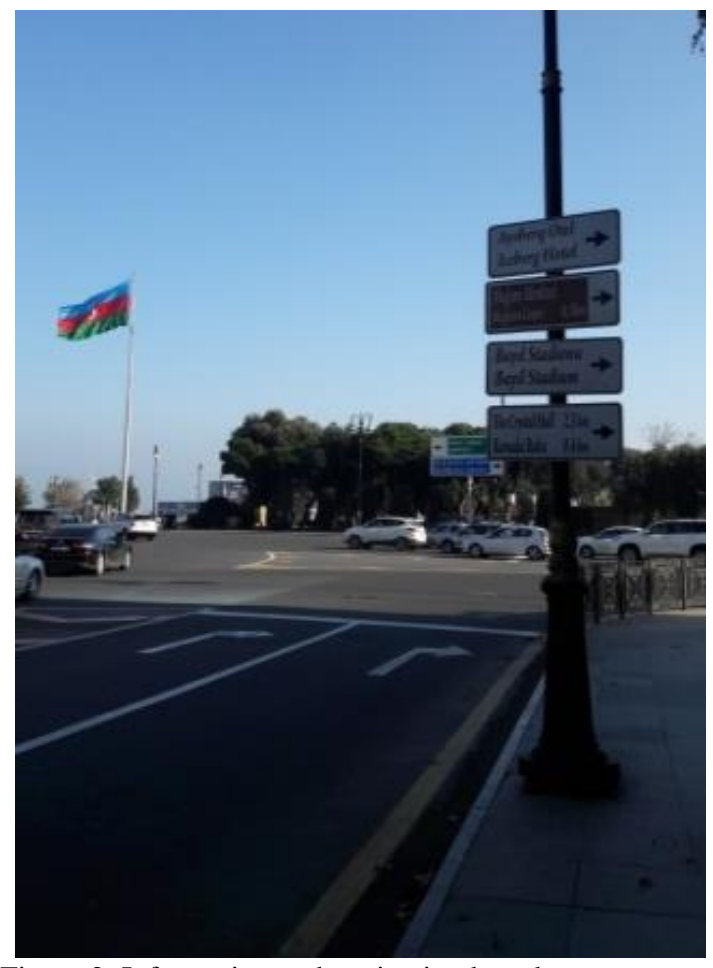

Figure 2. Information and navigation boards

An integrated approach to a barrier-free environment includes the following measures:

- Considering the needs and interests of people with various types of disability.

- Removing all kinds of obstacles

- Creating physical accessibility

- Creating information accessibility

- Developing policies and procedures for the provision of accessibility services

- $\quad$ Training of staff for working with persons with disabilities

- Identifying and creating an accessible environment area

- Defining objects, services and information Today we will face many challenges if we want to adjust open areas, streets and avenues, gardens and parks, the inner life of our cities to the principles of universal design. This process is not so simple and quick to solve. In many instances, it is even easier to implement these principles in new projects than in reconstruction projects. Therefore, at the initial stage of design it is necessary to be guided by 7 basic principles of Universal Design developed by Ronald Mace. Therefore, at least the navigation system should be as simple, logical and understandable as possible for everyone. Visual guidance should be repeated with tactile, audible signals and braille alphabets. Considering the high propensity of people with visual and hearing impairments to smell, landscape architects can use the scents of flowers in determining the direction. Furthermore, colorful plants can be used for navigation. People automatically remember the landmarks selected in the general context in respect of color and shape - public art ob- jects, greenery elements and small architectural patterns. It can assist people with visual and mental impairments conveniently and freely determine directions.

Besides, it is important that the parks, along with the open areas, are partially closed. While older people like open areas (figure 3), people with autism and visual impairments prefer calmer, more intimate and colouristically simple spaces (figure 4). Therefore, they will prefer the shading covered with lianas or benches surrounded by high plants above the wide alley near any fountain or children's playground. Surely, creating such special places in small gardens, inter-neighborhood and transit gardens is difficult or in some cases impossible, but in large parks, boulevards, forest parks it is mandatory.

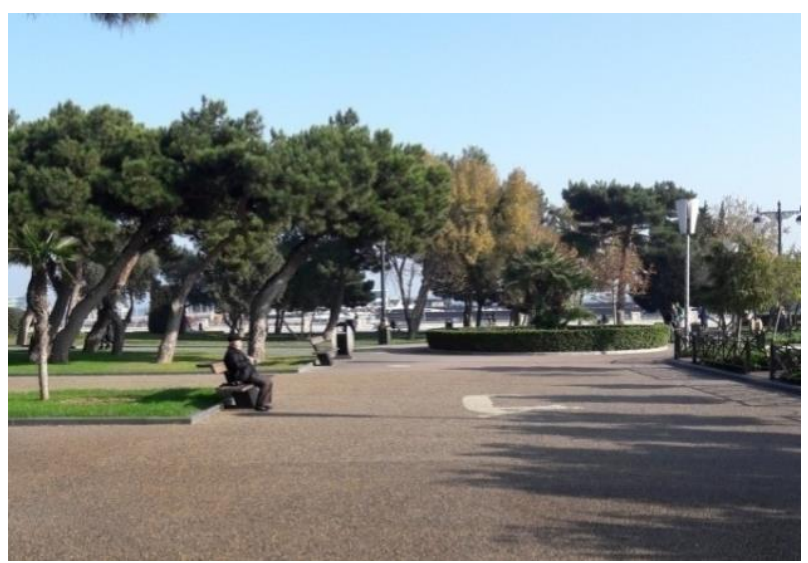

Figure 3. Open areas

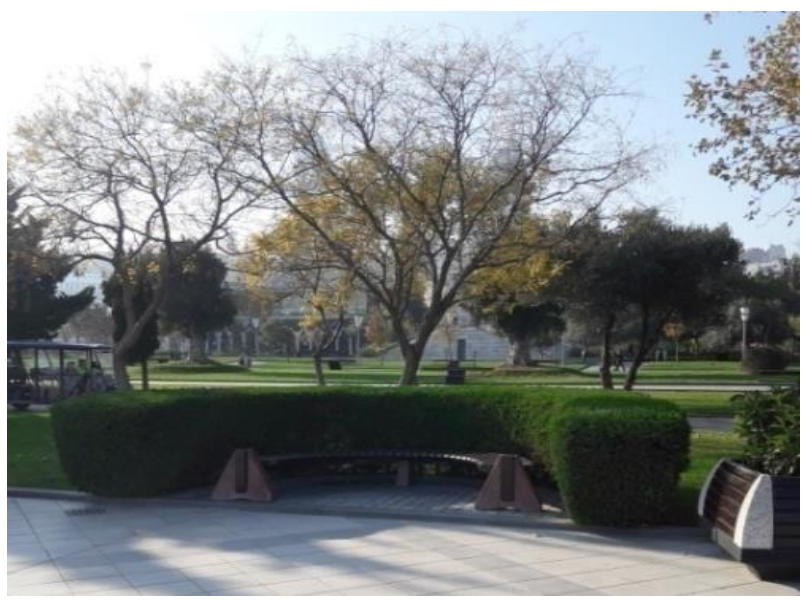

Figure 4. Simple spaces

Predictability is one of the important factors. Navigation boards should indicate not only directions but also distances to necessary objects - shady area, springs, small architectural patterns and sanitary facilities. Although it is not very important for healthy people, this data is necessary for people with disabilities. They must correctly calculate their strength according to the distance.

It is also important to properly illuminate open areas. We should ensure people's visits to the parks not only during the daytime, but also in the evenings. So, 
parks shouldn't lose their accessibility in the evening hours too. In this case, the spectrum, intensity and direction of light play an important role. The lights should not be too intense or weak. We should not forget the multifunctionality of the parks as well. Active recreation and sports areas should not only be for children and adolescents. Today there are also street fitness facilities for people with disabilities, which can be installed in outdoor sports venues.

In some cases, we face serious disadvantages in our parks and gardens. Although regular people do not feel these situations, persons using wheelchairs see and, in many cases, even fall into despair (Figure 5).

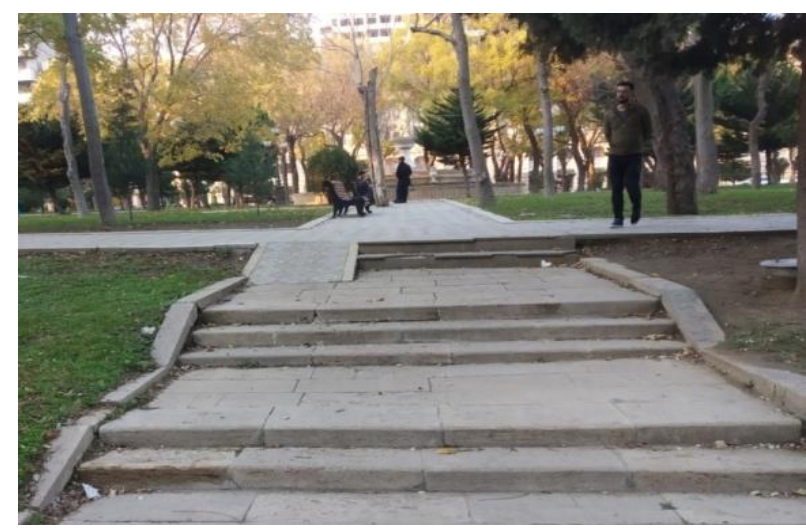

Figure 5. A ramp just in a staircase march in Officer's Park, Baku, Azerbaijan

While creating inclusive parks, attention should also be paid to the relief. Obviously, the inclination of the roads should be correctly set, that is, no more than $5 \%$ in length and $1-2 \%$ in width. While designing the roads, we must consider the will of the persons with disabilities, who use not only wheelchairs but also crutches (Figure 6). The floors of the roads should not be slippery. Especially in autumn and winter months. In this case, it is necessary to work out the drainage system and streams of rainwater properly. The availability of inclusive parks should start from the entrance area - the public transport stops and parking. The parking areas for people with disabilities should be wider than others so that the wheelchair user can easily and fully open the doors. According to the norms, this size constitutes $3.5 \times 5 \mathrm{~m}$. In general, all green locations need to be concentrated under a continuous network of green corridors under the design of landscape architecture of open areas. So that people with disabilities can move freely and safely from one place to another (Safronov, 2005; Stenfeld, 2012).

Another important factor is that public sanitary facilities don't meet inclusivity today. Such accessible sanitary facilities should be created not only in gardens and parks but also in all public areas. This work should not be limited only with the creation of such cabins. These measures should be addressed in a comprehensive manner, and the locations of such cabins should be identified by a special navigation system (repeated in braille alphabet), and the roads leading to these cabins should be equipped with tactile pavings and ramps, and cabins should be equipped with the necessary equipment. (Rahimli, 2018; Lazovsky, 2015).
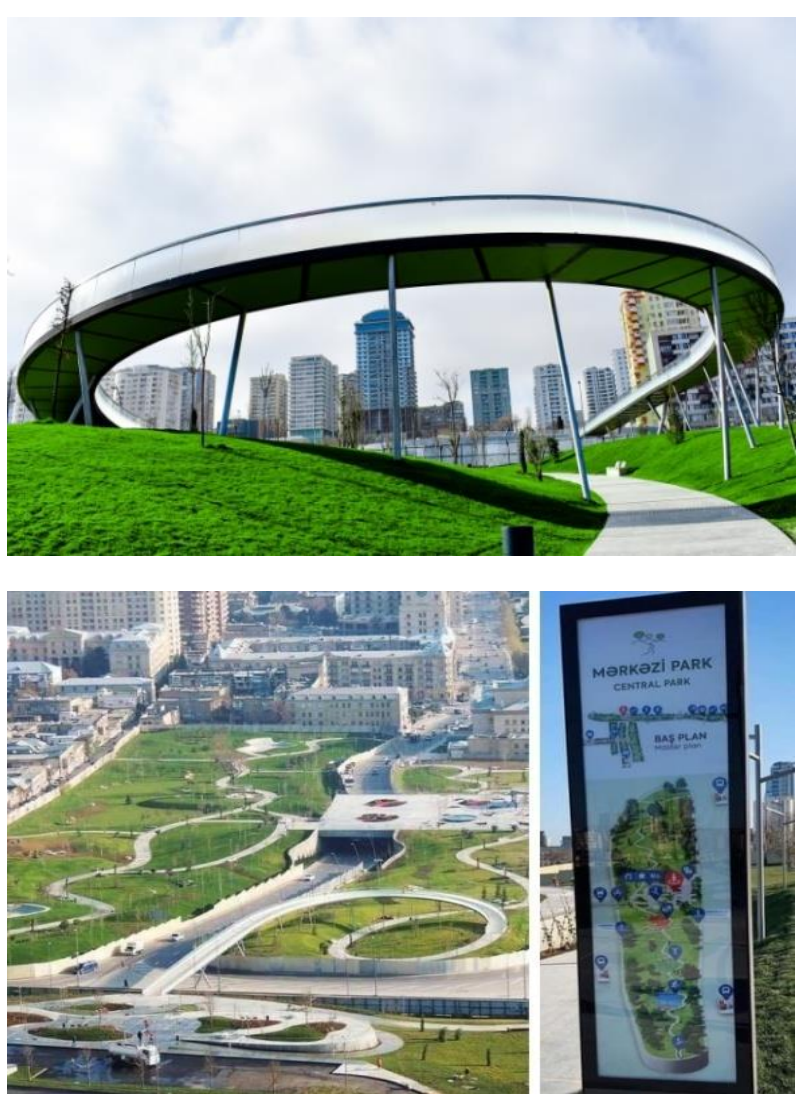

Figure 6. Central Park in the center of Baku, newly put into service

\section{Results}

In view of the above, it is regrettable to say that today our open areas are not inclusive, and there is no talk about the full accessibility of the environment. Taking into account sustainable development perspectives, it is necessary to use the principles of a systematic approach with the participation of all relevant institutions, organizations, social movements, architects and builders in forming the environment. It is necessary not only to design new buildings taking into account the accessibility of habitat and human needs, but also to adjust completed projects and restore old buildings. It is obvious that only architects, designers, especially landscape architects are able to cope with this problem at the initial stage of the implementation of comprehensive measures. In addition, the whole society should approach the issue with empathy. This process should not start with a project for the reconstruction of a site, but with a training process for professionals working in this field. We should today not only create accessible conditions based on world practice, but also train new generation specialists working in this field. Topics on accessibility should be included in core education programmes. Targeted work in this direction 
has already been carried out on a global scale. For instance, the Department of Architecture at the University of Buffalo offers a master's degree in Inclusive Design and Architecture. They train professionals who can provide equal opportunities for people of all categories and ages.

Recently, ASLA (American Society of Landscape Architects) has published a new Guideline on Universal Design (Isachenko, 2019; asla.org, 2020). Based on Ronald Mace's principles, this Guideline uses the concepts of multisensory, predictability, intuitiveness and others, and sets new requirements for parks, public areas and children's playgrounds. It stipulates that open areas should be accessible to all, regardless of physical, cognitive or mental abilities.

It should also be noted that little has been done recently in this direction in Azerbaijan. Thus, after gaining independence in Azerbaijan, people with disabilities began to acquire the status of equal members of society. At first, it began to be reflected in legislative and regulatory documents. The Republic of Azerbaijan has also studied and started applying UN Conventions and other international experience. One of the most important documents is the Law $\mathrm{On}$ the Rights of Persons with Disabilities approved by Presidential Decree \#213 of 31.05.2018 (Law of the Republic of Azerbaijan on the rights of person with disabilities, 2018). The document represents a purposeful scientific and methodological basis for the initiatives of architects and designers, production organizations and firms, public security authorities. Additionally, Union of Disabled People Organizations (UDPO) of the Republic of Azerbaijan developed rules for creating the necessary living and working conditions for the people with disabilities and limited mobility in the design of buildings and structures (Rahimli, 2017).

Over the course of time, the environment changes depending on a particular reason, natural or anthropogenic factors. Today we should try to make spaces inclusive, universal and accessible, for all.

\section{Conclusion}

Over time, the environment changes depending on one reason or another, natural or anthropogenic factors. We must work today to make the spaces more inclusive, universal and accessible - for everyone. This process, of course, is not a quick and inexpensive process. On the contrary, today there is a need for the implementation of purposeful and well-organized global social projects that require significant financial and time investment, not only for open spaces but also everywhere. In this case, public opinion, public opinion based on national and moral values, and tolerance towards the individual characteristics of persons with disabilities also play an important role.

\section{References}

1. ADA NATIONAL NETWORK, 2021, What is the Americans with Disabilities Act (ADA)?, https:// adata.org/learn-about-ada (1.02.2021).

2. AMERICAN SOCIETY OF LANDSCAPE ARCHITECTS, 2021, Professional practise: universal design, https://www.asla.org/universal design.aspx (1.02.2021).

3. FEFELOV V., 1986,. There are no disabled people in the USSR!, Overseas Publications Interchange Ltd, London.

4. ISACHENKO I., 2019, From the 'punitive' to therapeutic landscape, https://pragmatika.media/ot-karatelnogo-landshafta-k-terapevticheskomu/ (1.02.2021)

5. ISACHENKO I., 2019, The new elegance of cities. The evolution of inclusive design, https://pragmatika.media /novaja-jelegantnost-gorodov-jevoljucija-inkljuzivno go-dizajna/ (1.02.2021).

6. Law of the Republic of Azerbaijan On the Rights of Persons with Disabilities of May 31, 2018, No. 1153VQ. http://www.e-qanun.az/framework/39591.

7. LAZOVSKY N.A., 2015, Barrier-free environment for public open areas, buildings and structures: design features, Journal of Scientific Works, BNTU, 9: 134139.

8. RAHIMLI D., 2018, Accessible Azerbaijan. Baku the information book, Azeri Publishing House, Baku.

9. RAHIMLI D., 2020, Rules for creation of necessary living and activity conditions for persons with disabilities and limited mobility in designing of buildings and structures, http://udpo.az/category.php ?lang $=1 \&$ main $=49 \&$ content $=355$.

10. SAFRONOV E.A., 2005, On the organization of transport services for the disabled persons, Journal of Road transport, 10: 162-178.

11. STENFELD E., 2012, Universal Design. Designing Inclusive Environments, Wiley \& Sons, New Jersey.

12. The Convention on the rights of persons with disabilities, adopted by UN General Assembly resolution $6 / 106$ of 13.12 .2006

13. VOLKOVA N., 2016, Disabled people in the USSR: a story about a devastating custody, https:// www.miluserdie.ru/artijle/involidy-v-sssr-isturiyo-ub-unijhtuzhoyushhej-upeke/. 